\title{
Microscopic and molecular detection of Nosema spp. in honeybees of Turkey
}

\author{
Armagan Erdem Utuk ${ }^{1}$, Fatma Cigdem Piskin ${ }^{2}$, Ahmet Onur GiRIsGiN ${ }^{3}$, \\ Ozgur SELCUK ${ }^{3}$, Levent AYDIN ${ }^{3}$
}

\footnotetext{
${ }^{1}$ Faculty of Ceyhan Veterinary Medicine, Department of Parasitology, Cukurova University, Adana, Turkey ${ }^{2}$ Parasitology and Bee Diseases Laboratory, Central Veterinary Control and Research Institute, Ankara, Turkey

${ }^{3}$ Faculty of Veterinary Medicine, Department of Parasitology, Uludag University, Bursa, Turkey
}

Received 7 May 2015 - Revised 21 August 2015 - Accepted 16 September 2015

\begin{abstract}
In this study, we aimed to determine the prevalence of Nosema spp. in honeybees of Turkey. For this aim, adult honeybee (Apis mellifera) samples were collected from 1621 colonies within 95 apiaries located in 22 provinces of Turkey. Samples were examined microscopically. In case of positivity, spore identification was done by multiplex PCR. At the end of microscopic examination, Nosema spp. spores were detected in 7 out of 22 provinces $(31.8 \%)$, and 16 out of 95 colonies $(16.8 \%)$ that represent 1621 colonies. According to PCR results, 1 out of 16 isolates $(6.25 \%)$ was Nosema apis, and 15 out of 16 isolates (93.75\%) were Nosema ceranae. The result of our study indicated that N.ceranae is the dominant species in Turkey.
\end{abstract}

\section{Nosema apis / Nosema ceranae / Multiplex PCR / Turkey}

\section{INTRODUCTION}

Nosemosis is one of the most prevalent adult honeybee diseases. The etiologic agents of the disease are microsporidian parasites, Nosema apis and Nosema ceranae (Somerville and Hornitzky 2007). Disease spread by fecal-oral route in honeybee colonies. Adult bees get infection either by contaminated water and foods or when they come into contact with spores while they are cleaning the hives. After the spore ingestion, spores germinate in the midgut and then multiply. In a few weeks period, millions of spores occur and spread by feces (Fries 1997; Somerville and Hornitzky 2007).

Gastrointestinal disorders, shortened life span, flying failures, dead bee accumulation at hive

Corresponding author: A. Utuk, autuk@cu.edu.tr erdemutuk@hotmail.com

Manuscript editor: Klaus Hartfelder entrance, reduction of colony population and honey production, and even colony collapse are the symptoms of nosemosis (Fries 1997; Somerville and Hornitzky 2007; Higes et al. 2008).

$N$. apis is one of the first described microsporidian parasite and believed to be the only etiological agent of nosemosis in the European honeybee (Apis mellifera). However, nowadays, a new-described species, $N$. ceranae, is seen in Asia, Europe, and North and South America, spreading within the European honeybee colonies and starts to replace $N$. apis (Klee et al. 2007; Williams et al. 2008; Utuk et al. 2010).

Some studies showed that $N$. ceranae may be more pathogenic than N. apis, and infected colonies may collapse when they are not treated (Paxton et al. 2007; Somerville and Hornitzky 2007; Mayack and Naug 2009).

The disease is generally diagnosed by microscopical examination of spores. Nevertheless, spores of each species are very similar, and it is hard to make species identification by conventional microscopic examination (Fries et al. 1996; 
Martín-Hernández et al. 2007) Therefore, molecular techniques such as PCR (Polymerase Chain Reaction) (Higes et al. 2006), PCR-RFLP (Restriction Fragment Length Polymorphism) (Klee et al. 2007) and DNA sequencing have gained more prominence in the diagnosis of singular or mix infections (Fries et al. 1996; MartínHernández et al. 2007)

The aim of this study was to determine the prevalence of Nosema spp. in honeybees of Turkey by microscopic and molecular examination of adult honeybee samples, which were collected in a 7-year period.

\section{MATERIAL AND METHODS}

\subsection{Sample collection}

Adult honeybees (Apis mellifera) were collected from 1621 colonies within 95 apiaries $(17 \pm 1$ colony from each apiary) located in 22 provinces ( $4 \pm 1$ apiaries from each of 22 provinces) of Turkey between the years 2006 and 2011 and the months November and June. Study areas are summarized in Figure 1.

\subsection{Spore detection and DNA extraction}

95 apiary samples that represent 1621 colonies were examined. The abdomens of 20 adult honeybees (A. mellifera) from each sample were macerated in $3 \mathrm{~mL}$ of distilled water. Three drops of the suspension were placed on a slide under a cover slip and examined microscopically at $\times 40$ magnification, under brightfield or phase-contrast optics. In case of positivity, $1 \mathrm{~mL}$ of suspension was filtered and centrifuged for $5 \mathrm{~min}$ at $8000 \mathrm{rpm}$ and supernatants were removed. Spores were stored $-20{ }^{\circ} \mathrm{C}$ until they were used for DNA extraction (Utuk et al. 2010). Genomic DNA extraction was done from the pellets using DNeasy TM Tissue Kit (Qiagen, Hilden, Germany) by following the manufacturer's instructions. Prior to DNA extraction, pellets were washed for five times with phosphate buffer solution (PBS).

\subsection{PCR amplification}

To amplify partial 16S rRNA genes of $N$. ceranae and $N$. apis, 218MITOC-FOR (5'-cggcgacgat gtgatatgaaaatattaa-3'), 218MITOC-REV (5'- cccggtcattctcaaacaaaaaaccg-3') and 321 APIS-FOR (5'gggggcatgtcttgacgtactatgta-3'), 321 APIS-REV (5'ggggggcgtttaaaatgtgaaacaactatg- $3^{\prime}$ ) primer pairs were used in multiplex PCR (Martín-Hernández et al. 2007).

PCR was carried out in a final volume of $50 \mu \mathrm{L}$, containing $25.75 \mu \mathrm{L}$ DNase- and RNase-free steril distilled water (Biobasic, Inc), $5 \mu \mathrm{L}$ 10X PCR buffer, $5 \mu \mathrm{L}$ $25 \mathrm{mM} \mathrm{MgCl} 2,6 \mu \mathrm{L} 1 \mathrm{mM}$ dNTP mix, $1 \mu \mathrm{L}$ of each primer $(20 \mathrm{pmol}), 2.5 \mu \mathrm{L}$ of template DNA (100$200 \mathrm{ng}$ ), and $0.25 \mu \mathrm{L}$ of TaqDNA polymerase (1.25 IU) (MBI Fermentas). The PCR conditions were as follows: 2 min at $95^{\circ} \mathrm{C}$ (initial denaturation), $35 \mathrm{cy}$ cles of $1 \mathrm{~min}$ at $95^{\circ} \mathrm{C}, 1 \mathrm{~min}$ at $50^{\circ} \mathrm{C}, 1 \mathrm{~min}$ at $72{ }^{\circ} \mathrm{C}$, and finally 5 min at $72{ }^{\circ} \mathrm{C}$ (final extension). The PCR products were separated on agarose gels (1.5\%), stained with ethidium bromide and visualized and photographed on an UV transilluminator (Utuk et al. 2010).

\section{RESULTS}

At the end of microscopic examination, Nosema spp. spores were detected in 7 out of 22 provinces $(31.8 \%)$ and 16 out of 95 colonies $(16.8 \%)$ (Figure 1). All positive samples were from adult honeybees collected in the years 2009, 2010, and 2011. According to PCR results, 1 out of 16 isolates $(6.25 \%)$ was $N$. apis, which gave a 321 bp amplicon, and 15 out of 16 isolates $(93.75 \%)$ were N. ceranae, which gave a $218-$ 219 bp amplicon (Figure 2). While N. ceranae was detected in Ankara, Bursa, Erzurum, Kayseri, Mugla, and Zonguldak provinces, $N$. apis was only detected in Cankırı province of Turkey.

\section{DISCUSSION}

Nosemosis is an important widespread disease both in Turkey and in the world and has economic impact on beekeeping. To date, studies on nosemosis in Turkey have focused on detecting the prevalence of the disease with microscopic examination, such as 5-8.77\% in Elazig (Simsek et al. 2001; Simsek 2005), $15.74 \%$ in Kars (Topcu and Arslan 2004), $38.5 \%$ in Bingöl (Kutlu and Ekmen 2003) and 24-26.4 \% in Bursa (Aydin et al. 2001; Cakmak et al. 2003) provinces. Kutlu and Kaftanoglu (1990), studied the prevalence of Nosema spores on the colonies that were 


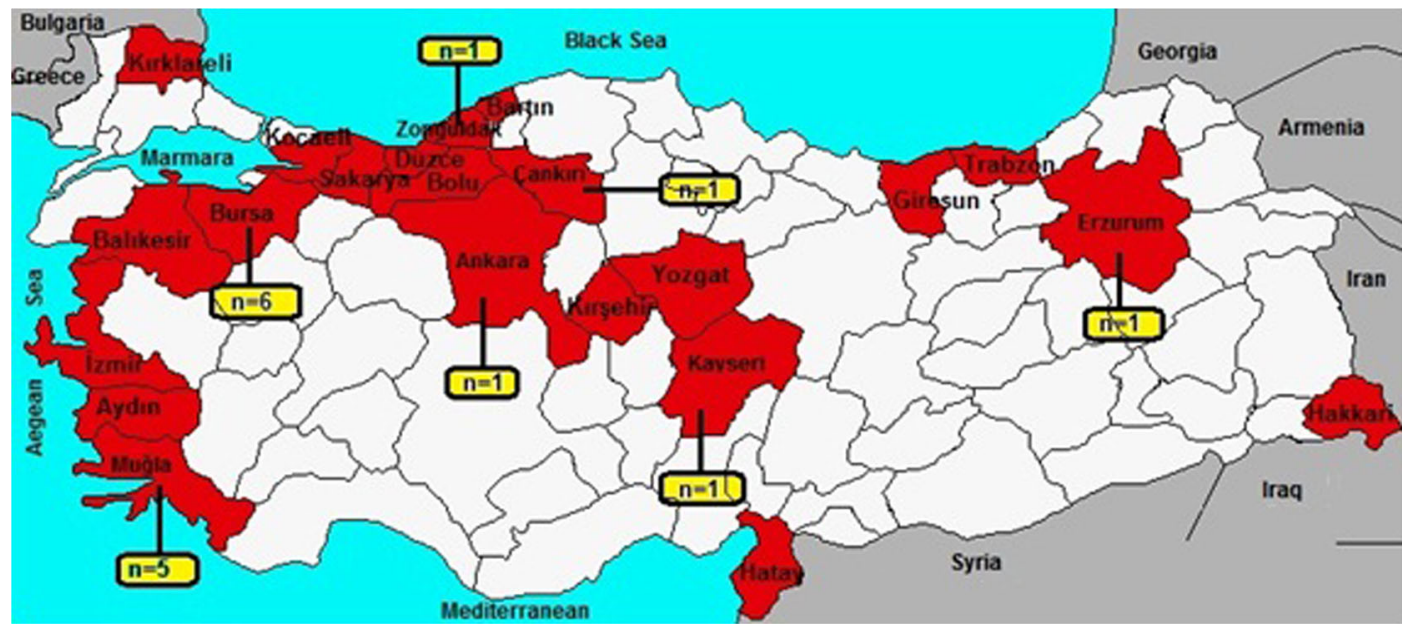

Figure 1. Map of Turkey showing study areas where the adult honeybee (A. mellifera) samples were collected and the number of positive colonies against Nosema spp. spores.

brought to Adana province for overwintering, Mugla and Aydin provinces for honeydew production. They examined 312 apiaries and sampled 1560 colonies and found that the Nosema infection was $31.3 \%$ in Mugla, $29.8 \%$ in Adana, $29.6 \%$ in Dalaman, $28.6 \%$ in Aydin, $25.7 \%$ in Datca, $25 \%$ in Milas, $23.8 \%$ in Fethiye, $23.3 \%$

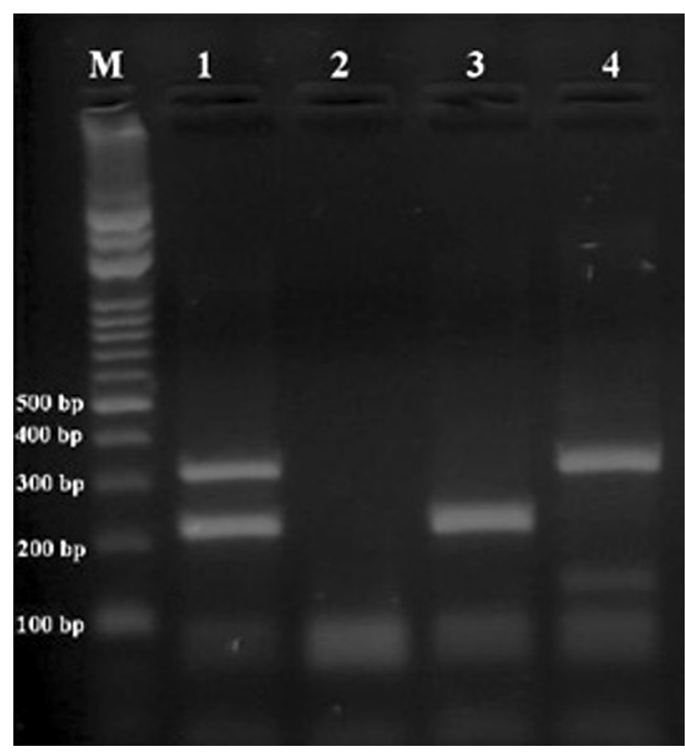

Figure 2. M: Marker 1: Positive controls of $N$. apis and $N$. ceranae 2: Negative control, 3: 218 bp amplicon of Ankara, Bursa, Erzurum, Kayseri, Mugla, and Zonguldak isolates 4: 321 bp amplicon of Cankırı isolate. in Koycegiz, and $20.5 \%$ in Marmaris. In a wide range research, Aydin et al. (2005) have studied on 230 colonies within 37 apiaries from 26 provinces and seven districts of Turkey, and they have found a prevalence of $60 \%$ at apiaries level and $14 \%$ at colony level. Utuk et al. (2011) evaluated the samples sent to the Veterinary Control Central Research Institute, Bee Diseases Laboratory between the years 2006 and 2010. In this period, they received 140 applications from 36 different provinces of Turkey and found the prevalence of nosemosis as $4.28 \%$. In this study, Nosema spp. spores were detected in 7 out of 22 provinces $(31.8 \%)$ and 16 out of 95 colonies $(16.8 \%)$.

According to the latest molecular studies, both $N$. ceranae and $N$. apis are present in Turkey. Utuk et al. (2010) detected $N$. ceranae for the first time in two bee samples that were sent to their laboratory from Samsun and Giresun provinces of Turkey by using multiplex PCR. Whitaker et al. (2011) have studied on 84 honeybee samples from 20 provinces of Turkey and detected $N$. ceranae in three samples from Artvin, Hatay, and Muğla and N.apis in four samples from Sivas, Izmir, Bitlis, and Gaziantep provinces by using conventional PCR and DNA sequencing. Muz et al. (2010) have reported $N$. ceranae and $N$. apis from Hatay and Southern Marmara by using conventional PCR. In this study, we reported N. ceranae in 15 samples from Ankara, Bursa, 
Erzurum, Kayseri, Mugla, and Zonguldak provinces and N. apis in 1 sample from Cankırı province of Turkey. According to our results, $N$. ceranae is the dominant species in Turkey.

Most studies showed that $N$. ceranae is more pathogenic and causes more energetic stress on honeybees than N. apis (Paxton et al. 2007; Mayack and Naug 2009; Martín-Hernández et al. 2011). As a result of the coevolution period of European honeybee and N. apis, they are well adapted to each other. But in the case of $N$. ceranae, this period is shorter than $N$. apis for the adaptation to European honeybee, and physiological adaptation mechanism in the hostparasite relationship may be less efficient. This causes increased appetite, more food consumption, shortened life span, decrease in energy levels, reduced colony population, and even colony collapse (Paxton et al. 2007; Mayack and Naug 2009). In addition to its effect on energetic stress, $N$. ceranae causes immunosuppression and provokes the secondary infections in honeybees (Antúnez et al. 2009). If the expansion of $N$. ceranae continues at this pace, there may be heavier colony losses in the future than in the past. Molecular studies that contain all regions in Turkey have to be performed and the current situation of the diseases has to be determined. In the light of the new data, awareness should be raised among beekeepers against the possible threat of $N$. ceranae.

\section{Détection microscopique et moléculaire de Nosema spp. chez les abeilles de Turquie}

\section{Nosema apis / Nosema ceranae / PCR multiplexe / Apis mellifera}

Die Identifizierung von Nosema spp. in der Türkei mitttels Mikroskopie und molekularer Methoden

Nosema apis / Nosema ceranae / Multiplex-PCR / Türkei / Apis mellifera

\section{REFERENCES}

Antúnez, K., Martín-Hernández, R., Prieto, L., Meana, A., Zunino, P., Higes, M. (2009) Immune suppression in the honeybee (Apis mellifera) following infection by Nosema ceranae (Microsporidia). Environ. Microbiol. 11, 2284-2290

Aydin, L., Gulegen, A.E., Cetinbas, H. (2001) Bursa yöresi bal arılarında Nosema apis'in (Zander, 1909) yaygınlığı. Bull. Am. Meteorol. Soc. 17, 6-8

Aydin, L., Cakmak, I., Gulegen, A.E., Wells, H. (2005) Honeybee nosema diseases in the Republic of Turkey. J. Apic. Res. 44, 196-197

Cakmak, I., Aydın, L., Gulegen, A.E. (2003) Güney Marmara Bölgesinde balarısı zararlıları ve hastalıkları. Uludağ Arıcılık Derg. 1, 33-35

Fries, I. (1997) Protozoa In: Morse R.A., Flottum K. (Eds), Honey bee pests, predators, diseases. A I Root Company, USA. pp. 59-76

Fries, I., Feng, F., da Silva, A., Slemenda, S.B., Pieniazek, N.J. (1996) Nosema ceranae n. sp. (Microspora, Nosematidae), Morphological and molecular characterization of a microsporidian parasite of the Asian honey bee Apis cerana (Hymenoptera, Apidae). Eur. J. Parasitol. 32, 356-365

Higes, M., Hernández, R.M., Meana, A. (2006) Nosema ceranae, a new microsporidian parasite in honeybees in Europe. J. Invertebr. Pathol. 92, 93-95

Higes, M., Hernández, R.M., Botías, C., Bailón, E.G., González-Porto, A.V., Barrios, L., Del Nozal, M.J., Bernal, J.L., Jiménez, J.J., Palencia, P.G., Meana, A. (2008) How natural infection by Nosema ceranae causes honeybee colony collapse. Environ. Microbiol. 10, 2659-2669

Klee, J., Besana, A.M., Genersch, E., Gisder, S., Nanetti, A., et al. (2007) Widespread dispersal of the microsporidian Nosema ceranae, an emergent pathogen of the western honey bee. Apis mellifera. J. Invertebr. Pathol. 96, 1-10

Kutlu, M.A., Ekmen, F. (2003) Bingöl yöresi bal arılarında (Apis mellifera) nosema hastalığının varlığı ve enfeksiyon oranı. Teknik Arıcılık 79, 24-26

Kutlu, M.A., Kaftanoglu, O. (1990) A study on the distribution and infection rate of nosema (Nosema apis) disease of adult honey bees (Apis mellifera L.). Cukurova University, Institute of Natural and Applied Sciences, J. Sci. Eng. 4 (2), 141-149

Martín-Hernández, R., Meana, A., Prieto, L., Salvador, A.M., Bailon, E.G., Higes, M. (2007) Outcome of colonization of Apis mellifera by Nosema ceranae. Appl. Environ. Microbiol. 73, 6331-6338

Martín-Hernández, R., Botías, C., Barrios, L., MartínezSalvador, A., Meana, A., Mayack, C., Higes, M. (2011) Comparison of the energetic stress associated with experimental Nosema ceranae and Nosema apis infection of honeybees (Apis mellifera). Parasitol. Res. 109, 605-612

Mayack, C., Naug, D. (2009) Energetic stress in the honeybee Apis mellifera from Nosema ceranae infection. J. Invertebr. Pathol. 100, 185-188

Muz, M.N., Girisgin, A.O., Muz, D., Aydin, L. (2010) Molecular detection of Nosema ceranae and Nosema 
apis infections in Turkish apiaries with collapsed colonies. J. Apic. Res. 49 (4), 342

Paxton, R.J., Klee, J., Korpela, S., Fries, I. (2007) Nosema ceranae has infected Apis mellifera in Europe since at least 1998 and may be more virulent than Nosema apis . Apidologie 38, 558-565

Simsek, H. (2005) Elazığ yöresi bal arılarında bazı parazit ve mantar hastalıklarının araștırılması. Ankara Üniv Vet Fak Derg. 52, 123-126

Simsek, H., Dilgin, N., Gultekin, I. (2001) Elazı̆̆ yöresinde bulunan arı ișletmelerinde nosematosisin yaygınlığı. Etlik Vet Mikrobiyol Derg. 12,49-51

Somerville, D, Hornitzky, M. (2007) Nosema disease. http://www.dpi.nsw.gov.au/_data/assets/pdf_file/ 0003/177519/nosemadisease.pdf, 2007. Accession date: 27.03 .2015
Topcu, B., Arslan, M.O. (2004) Kars yöresindeki balarılarında nosemosis'in yaygınlığı. Uludağ Arıcılık Derg. 4, 164-170

Utuk, A.E., Piskin, F.C., Kurt, M. (2010) First molecular detection of Nosema ceranae in Turkey. Ankara Üniv Vet Fak Derg. 57, 275-278

Utuk, A.E., Piskin, F.C., Deniz, A., Balkaya, I. (2011) A retrospective study on varroosis and nosemosis. Etlik Vet. Microbiyol Deg. 22, 11-15

Whitaker, J., Szalanski, A.L., Kence, M. (2011) Molecular detection of Nosema ceranae and Nosema apis from Turkish honey bees. Apidologie. 42, 174-180

Williams, G.R., Shafer, A., Rogers, R., Shutler, D., Stewart, D.T. (2008) First detection of Nosema ceranae, a microsporidian parasite of European honey bees (Apis mellifera) in Canada and central USA. J. Invertebr. Pathol. 97, 189-192 